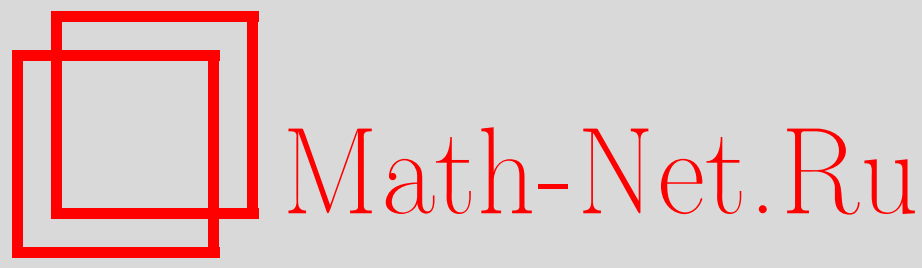

С. Л. Яковлев, О С. П. Меркурьеве, ТМФ, 2016, том 186, номер 1, 3-4

DOI: https://doi.org/10.4213/tmf9071

Использование Общероссийского математического портала Math-Net.Ru подразумевает, что вы прочитали и согласны с пользовательским соглашением http://www.mathnet.ru/rus/agreement

Параметры загрузки:

IP : 54.197 .130 .99

26 апреля 2023 г., 15:43:03

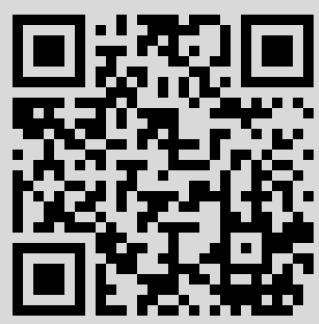




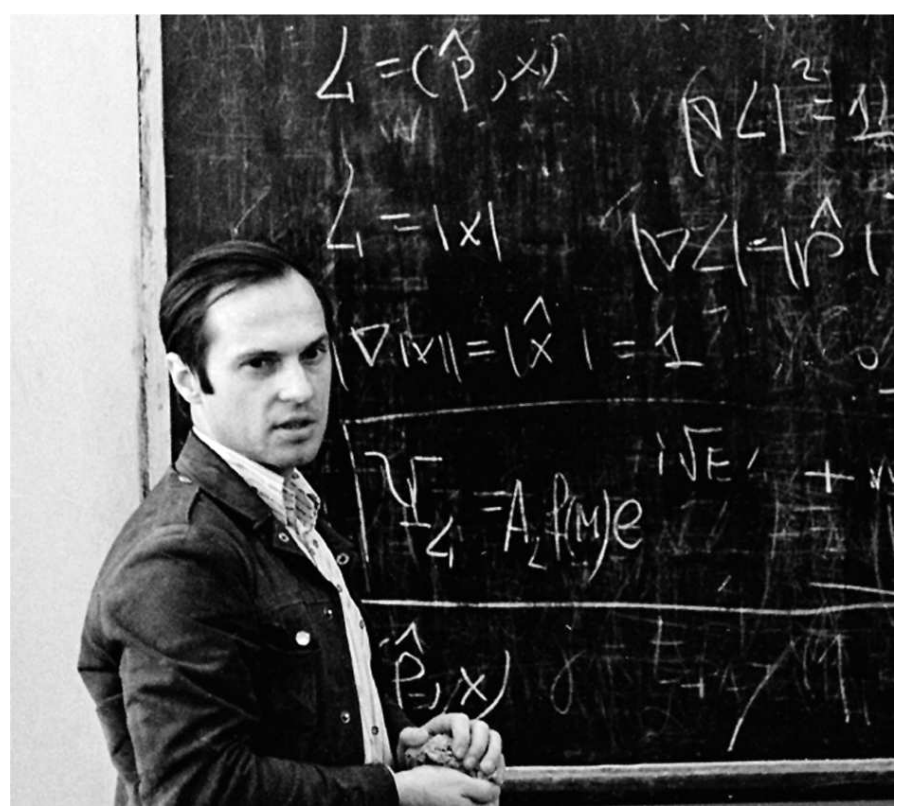

\section{О С. П. Меркурьеве}

Если бы жизнь академика Станислава Петровича Меркурьева не оборвалась внезапно в 1993 году на сорок девятом году жизни, то в 2015 году ему бы исполнилось семьдесят. За свою довольно короткую жизнь С.П. Меркурьев оставил заметный след в науке. Классическими стали его исследования по квантовой теории систем нескольких частиц. В числе основных результатов - спектральные тождества для трехчастичных матриц рассеяния и их приложения к вириальным разложениям статистической физики, изучение асимптотических свойств волновых функций трехчастичных систем в конфигурационном пространстве и разработка на их основе вариационных принципов для амплитуд трехчастичных реакций, решение ряда математических и вычислительных проблем квантовой теории рассеяния для систем трех частиц с кулоновским взаимодействием, создание нового подхода к решению проблемы $N$ тел в квантовой механике на основе матричных дифференциальных уравнений в конфигурационном пространстве, решение задачи трех тел с сингулярными потенциалами, задаваемыми граничными условиями, обширные исследования по физике малонуклонных систем, структуре адронов, по физике атомных и мезомолекулярных систем.

В настоящем номере журнала собраны работы некоторых учеников и коллег С. П. Меркурьева. Эти работы могут служить продолжением или развитием ряда методов и идей, заложенных в его работах. Авторы настоящего выпуска журнала надеются, что представленные работы послужат хорошим вкладом в дело сохранения памяти о талантливом ученом и прекрасном человеке Станиславе Петровиче Меркурьеве. 